\title{
PENGARUH PEMBERIAN JUS SEMANGKA KUNING (Citrullus lanatus) TERHADAP KELELAHAN OTOT ANAEROBIK PADA ATLET SEPAKBOLA
}

\author{
THE EFFECT OF GIVING YELLOW WATERMELON JUICE (Citrullus lanatus) ON ANAEROBIC MUSCLE WEAKS IN \\ FOOTBALL ATLET
}

\author{
Alamanda Devi Maharani ${ }^{1}$, Ana Yuliah Rahmawati ${ }^{2}$, Enik Sulistyowati ${ }^{2}$, Setyo Prihatin ${ }^{2}$ \\ ${ }^{1}$ Mahasiswa Jurusan Gizi Politeknik Kesehatan Kemenkes Semarang \\ ${ }^{2}$ Dosen Jurusan Gizi Politeknik Kesehatan Kemenkes Semarang
}

\section{ABSTRACT}

Background : Muscle fatigue in anaerobic activity occured, when athletes have high intensity activities. The accumulation of lactic acid in muscle and blood could inhibit muscle contraction caused low concentration and performance. Sitrulin in yellow watermelon (Citrullus lanatus) juice can delay muscle fatigue in anaerobic activity.

Objective : To know the effect of Yellow Watermelon Juice (Citrullus lanatus) To Anaerobic Muscle Fatigue Index Athletes.

Methods : This study used quasi experimental design with a pre-post test design group control design. The fourteen athletes who were randomly divided into control groups and treatment groups. The control group was given a placebo and the treatment group was given a $500 \mathrm{ml}$ watermelon juice with a dose of 1,8gr of sitrulin during seven days. Yellow watermelon (Citrullus lanatus) juice are given 60 minutes before the test done. Anaerobic muscle fatigue in soccer athletes were measured using a RAST (Running-based Anaerobic Sprint Test) by calculating the Muscle Fatigue Index. Data were analyzed by Independent t-test.

Results : In this study there was an increase category of muscle fatigue index from good category (0.21-3.31) to very good category (<0.21), although both control and treatment group not significant different statistically $(p=$ 0,532 ). The mean initial muscle fatigue index of the treatment and control group respectively $(0.1157 \pm 0.05)$ and $(0.1486 \pm 0.65)$. The mean final muscle fatigue index of the treatment and control group respectively $(0.1229 \pm$ $0.04)$ and $(0.1371 \pm 0.03)$.

Conclusion : The adduction of yellow watermelon juice (citrullus lanatus) during seven days did not affect the reduction of anaerobic muscle fatigue $(p=0,532)$.

Keywords : athlete, soccer, yellow watermelon (Citrullus lanatus) juice, muscle fatigue index

\section{ABSTRAK}

Latar Belakang : Kelelahan otot pada aktivitas anaerobik terjadi karena atlet sepakbola memiliki akitivitas dengan intensitas tinggi. Akumulasi asam laktat dalam otot dan darah dapat menghambat kontraksi otot menyebabkan penurunan konsentrasi dan performa atlet. Sitrulin dalam jus buah semangka kuning (Citrullus lanatus) dapat menunda kelelahan otot pada aktivitas anaerobik.

Tujuan : Mengetahui pengaruh pemberian jus semangka kuning (Citrullus lanatus) terhadap kelelahan otot anaerobik pada atlet sepakbola.

Metode : Jenis penelitian adalah penelitian quasi experiment dan menggunakan rancangan Pretest Posttest Control Group Design. Jumah responden 14 atlet sepakbola yang dibagi secara acak menjadi kelompok kontrol dan kelompok perlakuan. Kelompok kontrol diberikan plasebo berupa air putih dan kelompok perlakuan diberikan jus semangka $500 \mathrm{ml}$ dengan dosis 1,8gr sitrulin selama 7 hari. Buah semangka diberikan 60 menit sebelum tes dilakukan. Kelelahan otot anaerob pada atlet sepak bola diukur menggunakan RAST (Running-based Anaerobic Sprint Test) dengan menghitungindeks kelelahan otot. Data dianalisis dengan uji Independent T-test.

Hasil : Pada penelitian ini terjadi peningkatan kategori indeks kelelahan otot dari kategori baik $(0,21-3,31)$ menjadi kategori sangat baik $(<0,21)$, meskipun antara kedua kelompok kontrol dan perlakuan tidak ada 
perbedan yang signifikan secara statistik $(p=0,532)$. Rerata indeks kelelahan otot awal pada kelompok perlakuan $(0,1157 \pm 0,05)$ dan kelompok kontrol $(0,1486 \pm 0,65)$. Rerata indeks kelelahan otot akhir pada kelompok perlakuan $(0,1229 \pm 0,04)$ dan kelompok kontrol $(0,1371 \pm 0,03)$.

Kesimpulan : Pemberian jus semangka kuning (citrullus lanatus) selama 7 haritidak berpengaruh terhadap pengurangan kelelahan otot anaerobik $(p=0,532)$.

Kata Kunci : Atlet, sepakbola, Jus Semangka Kuning (Citrullus lanatus), Indeks Kelelahan Otot Anaerobik, RAST (Running-based Anaerobic Sprint Test)

\section{PENDAHULUAN}

Olahraga sepakbola merupakan akitivitas dengan intensitas tinggi yang membutuhkan energi dalam waktu cepat dan singkat, kelelahan otot anaerobik merupakan masalahyang sering dialami atlet sepakbola saat pertandingan maupun latihan disebabkan menurunnya kemampuan berkontraksi neuromuscular junction yangtidak mampu meneruskan rangsang sehingga terjadi akumulasi asam laktat dalam otot dan darah, apabila terjadi pada atlet terus menerus maka atlet tidak dapat berkonsentrasi dan performa atlet dapat menurun. ${ }^{1,2}$

Functional food merupakan olahan makanan atau minuman bergizi yang mengandung bahan atau unsur yang berperan untuk membantu fungsi khusus bila dikonsumsi yaitu mengatur dan mempengaruhi proses dalam tubuh. ${ }^{3,4}$ Semangka kuning (citrullus lanatus) merupakan buah fungsional yang mengandung asam amino salah satunya sitrulin. Pemberian minuman fungsional jus semangka kuning (citrullus lanatus) dengan kandungan asam amino sitrulin, berfungsi mempercepat penguraian asam laktat sehingga memungkinkan kinerja fisik yang lebih baik yaitu latihan intensif dan pemulihan kelelahan otot lebih cepat, sehingga dapat menunda kelelahan otot. ${ }^{5,6}$

Penelitian Martínez-Sánchez et al (2017) bahwa mengkonsumsi NW (Natural Watermelon) dan EW (Enriched Watermelon) menunjukkan bahwa 1,17 g L-Sitrulin asam amino cukup membantu mengurangi rasa sakit fisik. Penelitian Bendahan et al (2002) menunjukkan bahwa mengkonsumsi sitrulin mengurangi kelelahan, meningkatkan laju produksi ATP oksidatif selama latihan sebesar $34 \%$, dan pemulihan fosfokreatin $20 \%$ setelah berolahraga. ${ }^{7}$

Tujuan penelitian ini untuk menganalisis pengaruh pemberian sitrulin yang terkandung pada jus semangka kuning (Citrullus lanatus) terhadap kelelahan otot anaerobik pada atlet sepakbola.

\section{METODE}

Rancangan Penelitian menggunakan Pretest Posttest Control Group Design. Subjek yang memenuhi kriteria inklusi dikelompokkan menjadi 2, yaitu kelompok perlakuan diberikan jus semangka kuning (citrullus lanatus) $500 \mathrm{ml}$ dengan dosis sitrulin 1,8 gr dan kelompok kontrol (tidak diberi).

Subjek yang berpartisipasi dalam penelitian adalah siswa atlet binaan PPLOP Jawa Tengah yang masih dalam jenjang pendidikan Sekolah Menengah Atas (SMA) yang berjenis kelamin laki-laki dengan kisaran usia 15 - 19 tahun ,berjumlah 20 orang dan penelitian dilakukan selama 7 hari (22 - 29 Maret 2018). Subjek penelitian berjenis kelamin laki-laki dan bersedia menjadi sampel, sehat jasmani dan rohani, bersedia di wawancarai dan sanggup mengikuti penelitian sampai akhir.

Berdasarkan perhitungan didapatkan jumlah masing-masing kelompok 7 sampel yang diperoleh secara random sapling dengan $20 \%$ (3 sampel) sebagai cadangan, sehingga total sampel dalam penelitian ini adalah 20 sampel. Dropout sejumlah 6 orang, 2 orang memiliki cedera pada bagian kaki, 2 orang tidak mengikuti pengukuran awal recall asupan zat gizi, cairan dan indeks kelelahan otot dengan metode RAST, 1 orang alergi jus semangka kuning serta 1 orang tidak mengikuti pengukuran akhir indeks kelelahan otot dengan metode RAST.

Kelompok perlakuan dalam penelitian ini diberikan jus buah semangka kuning (citrullus lanatus) sebesar $500 \mathrm{ml}$ dengan dosis 1,8 gram yang dikonsumsi sebagai minuman cairan saat latihan, sedangkan kelompok kontrol tidak diberikan jus semangka kuning. Variabel dependent yaitu indeks kelelahan otot subjek yang diukur pada awal dan akhir intervensi menggunakan metode RAST (Running-based Anaerobic Sprint Test). Variabel independent yaitu pemberian jus semangka kuning (citrullus lanatus).

Instrumen yang digunakan terdiri dari formulir identitas, formulir informed concern, formulir pengecekan indeks kelelahan otot awal dan akhir, formulir recall $3 \times 24$ jam dan formulir Fluid frequency. Penentuan status gizi dari hasil pengukuran BB yang diukur menggunakan timbangan digital dan TB yang diukur menggunakan microtoice.

Data indeks kelelahan otot diukur menggunakan metode RAST (Running-based 
Anaerobic Sprint Test)sebelum dan sesudah intervensi. Perbedaan indeks kelelahan otot sebelum dan sesudah diberikan perlakuan diuji dengan Independent t-test.

\section{HASIL PENELITIAN}

1. Karakteristik Subjek Penelitian menurut, umur, status gizi, persen lemak tubuh

Karakteristik subjek penelitian pada penelitian ini meliputi; umur, status gizi dan persen lemak tubuh. Masa remaja merupakan masa peralihan dari masa anak-anak menuju masa dewasa. Menurut World Health Organitation (2011), penggolongan umur masa remaja terbagi atas; masa remaja awal (10-13 tahun), masa remaja tengah (14-16 tahun) dan masa remaja akhir (17-19 tahun). Status gizi adalah kondisi fisik seseorang sebagai ekspresi keadaan dari keseimbangan antara jumlah asupan zat gizi dan jumlah yang dibutuhkan oleh tubuh. Persen lemak tubuh merupakan persentase dari perbandingan bobot massa jaringan lemak dan non lemak (fat free mass) pada tubuh yang menggambarkan komposisi tubuh optimal pada atlet. ${ }^{12}$ Hasil analisis dapat dilihat pada tabel 1.

\begin{tabular}{|c|c|c|c|c|}
\hline \multirow[t]{2}{*}{ Variabel } & \multicolumn{2}{|c|}{ Kelompok Perlakuan } & \multicolumn{2}{|c|}{ Kelompok Kontrol } \\
\hline & $\mathbf{N}$ & $\%$ & $\mathbf{N}$ & $\%$ \\
\hline \multicolumn{5}{|l|}{ Usia } \\
\hline $13-15$ tahun & 1 & $14,3 \%$ & 0 & $0 \%$ \\
\hline $16-19$ tahun & 6 & $85,7 \%$ & 7 & $100 \%$ \\
\hline \multicolumn{5}{|l|}{ Status Gizi } \\
\hline Normal $(18,5-22,9)$ & 5 & $71,4 \%$ & 1 & $14,3 \%$ \\
\hline Overweight $(\geq 23,0)$ & 2 & 28,65 & 6 & $85,7 \%$ \\
\hline \multicolumn{5}{|l|}{ Persen Lemak Tubuh } \\
\hline $\operatorname{Normal}(\geq 10 \%-\leq 20 \%)$ & 7 & $100 \%$ & 6 & $85,7 \%$ \\
\hline Overfat $(\geq 20 \%-\leq 24 \%)$ & 0 & $0 \%$ & 1 & $14,3 \%$ \\
\hline
\end{tabular}

Karakteristik subjek penelitian paling banyak terdapat pada rentang usia 16-19 tahun (late adolescent) sebesar 85,7\% pada kelompok perlakuan dan $100 \%$ pada kelompok kontrol. Penelitian yang dilakukan oleh I Made Yoga menunjukkan bahwa dengan bertambahnya umur akan berpengaruh terhadap komposisi tubuh dan kebugaran jasmani meningkat pada masa anak-anak sampai mencapai maksimal pada usia 25-30 tahun, kemudian akan terjadi penurunan kapasitas fungsional dari seluruh tubuh kira-kira sebesar 0,8-1\% per tahun, penurunan tersebut dapat dikurangi dengan cara meningkatkan intenstas frekuensi olahraga. ${ }^{8}$

Karakteristik subjek penelitian menurut status gizi menunjukkan bahwa pada kelompok perlakuan sebagian besar memiliki status gizi normal yaitu sebesar $71,4 \%$ dan pada kelompok kontrol sebagian besar memiliki status gizi overweight yaitu sebesar $85.7 \%$. Atlet memiliki status gizi kurus maka dapat mengalami kerusakan jaringan tubuh sedangkan seorang atlet dengan status gizi gemuk, maka dapat menyebabkan penurunan kemampuan gerakan tubuh secara maksimal. Kelebihan berat badan umumnya akan menyebabkan kelelahan yang jauh lebih dini, sedangkan seseorang yang memiliki status gizi kurus, akan mengalami penurunan kekuatan, kelenturan dan ketangkasan serta penurunan daya tahan kardiovaskular. ${ }^{9}$ Komposisi tubuh dan berat badan berkontribusi terhadap performa latihan. Berat badan berpengaruh terhadap kecepatan, daya tahan dan power seorang atlet, sedangkan komposisi tubuh (massa lemak dan massa tubuh bebas lemak) dapat menghasilkan kekuatan, kelincahan dan penampilan atlet. ${ }^{10}$ Pemantauan berat badan, tinggi badan,kondisi lemak tubuh dan riwayat status gizi yang optimal pada atlet perlu dilakuakan secara berkala. Keseimbangan antara IMT dan persentase lemak tubuh perlu dijaga karena merupakan dua hal yang saling mempengaruhi penambahan berat badan berhubungan dengan peningkatan proporsi lemak tubuh. ${ }^{11}$

Karakteristik subjek penelitian menurut persen lemak tubuh menunjukkan bahwa sebagian besar subjek penelitian memiliki persen lemak tubuh normal dengan persentase $100 \%$ pada kelompok perlakuan dan $85,7 \%$ pada kelompok kontrol. Penurunan massa otot pada atlet memberikan dampak negatif pada metabolisme tubuh, kekuatan, dan daya tahan, sedangkan persen lemak tubuh yang berlebih dapat mempengaruhi daya tahan sistem kardiovaskuler, komposisi tubuh, daya tahan otot, kekuatan otot, dan kelentukan. ${ }^{10}$

2. Karakteristik Subjek Penelitian Menurut Kategori Tingkat Asupan Energi, Protein, Lemak, Karbohidrat dan Cairan Selama Penelitian

Kategori tingkat asupan zat gizi dan cairan berdasarkan AKG 2013 dibagi menjadi : Defisit apabila asupan zat gizi dan cairan (<60\%), kurang apabila asupan zat gizi dan cairan (60 $69 \%)$, sedang apabila asupan zat gizi dan cairan (70 - $79 \%$ ), baik apabila asupan zat gizi dan cairan (80 - $109 \%$ ) dan lebih apabila asupan zat gizi dan cairan (>110\%). Hasil dapat dilihat pada Tabel 2. 


\begin{tabular}{|c|c|c|c|c|}
\hline \multirow{2}{*}{$\begin{array}{c}\text { Asupan Gizi dan Cairan Selama } \\
\text { Penelitian }\end{array}$} & \multirow{2}{*}{\multicolumn{2}{|c|}{$\begin{array}{c}\text { Kelompok Perlakuan } \\
(\mathrm{n}=7)\end{array}$}} & \multicolumn{2}{|c|}{$\begin{array}{c}\text { Kelompok Kontrol } \\
(\mathbf{n}=7)\end{array}$} \\
\hline & & & & $\%$ \\
\hline \multirow{2}{*}{$\begin{array}{l}\text { Energi } \\
\text { Kurang }(60-69 \%) \\
\text { Sedang }(70-79 \%)\end{array}$} & 1 & $14,3 \%$ & 3 & \\
\hline & 3 & $42,9 \%$ & 4 & $57,1 \%$ \\
\hline & 3 & $42,9 \%$ & 0 & \\
\hline \multicolumn{4}{|l|}{ Protein } & \\
\hline $\begin{array}{l}\text { Baik }(80-109 \%) \\
\text { Lebih }(>110 \%)\end{array}$ & $\begin{array}{l}1 \\
6\end{array}$ & $\begin{array}{l}14,3 \% \\
85,7 \%\end{array}$ & $\begin{array}{l}0 \\
7\end{array}$ & $\begin{array}{c}0 \% \\
100 \%\end{array}$ \\
\hline
\end{tabular}

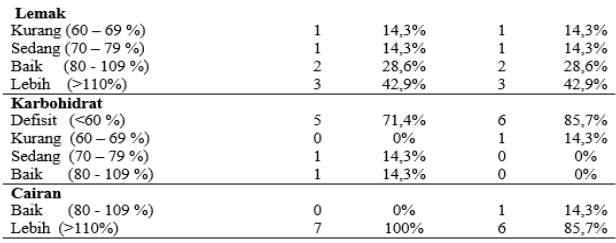

Kategori tingkat asupan zat gizi berdasarkan AKG pada kelompok perlakuan, rata-rata kategori tingkat asupan energi termasuk dalam kategori sedang (70-79\%) dan baik (80-109\%) dengan persentase 42,9\%, rata-rata tingkat asupan protein, lemak dan cairan termasuk dalam kategori lebih (>110\%) dengan persentase $85,7 \%$, 42,9\% dan $100 \%$, rata-rata tingkat asupan karbohidrat termasuk dalam kategori defisit $(<60 \%)$ dengan persentase $71,4 \%$.

Kategori tingkat asupan zat gizi berdasarkan AKG pada kelompok kontrol, rata-rata tingkat asupan energi termasuk dalam kategori sedang (70 - $79 \%$ ) dengan persentase $57,1 \%$, rata-rata tingkat asupan protein, lemak dan cairan termasuk dalam kategori lebih $(\geq 110 \%)$ dengan persentase $100 \%, 42,9 \%$ dan $85,7 \%$, sedangkan rata-rata tingkat asupan karbohidrat 85,7\% termasuk dalam kategori defisit (<60\%).

Kelompok perlakuan dan kelompok kontrol memiliki tingkat asupan protein, lemak, cairan termasuk dalam kategori tingkat asupan lebih (>110\%), tingkat asupan karbohidrat defisit $(<60 \%)$ dan asupan energi dalam tingkat asupan sedang hingga baik.

3. Perbedaan Indeks Kelelahan Otot Subjek Penelitian Sebelum dan Sesudah Perlakuan antara Kelompok Perlakuan dan Kontrol

Perbedaan indeks kelelahan otot pada kelompok perlakuan dan kelompok kontrol dalam satu minggu dengan pengukuran indeks kelelahan otot sebelum penelitian dan sesudah penelitian, yang diukur pada hari ke-1 dan ke-7 penelitian. Hasil Uji Independent t-test antara indeks kelelahan otot pada kelompok perlakuan dan kelompok kontrol dapat dilihat pada Tabel 3.

Tabel 3.

Perbedaan indeks kelelahan otot subjek penelitian sebelum dan setelah satu minggu penelitian

\begin{tabular}{lccc}
\hline \multirow{2}{*}{ Variabel } & \multicolumn{3}{c}{ Kelompok } \\
\cline { 2 - 4 } & \multicolumn{2}{c}{ Perlakuan (n=7) } & Kontrol $(\mathbf{n}=7)$ \\
\cline { 2 - 4 } & Rerata \pm SD & Rerata \pm SD & $p$ \\
\hline Indeks Kelelahan Otot awal & $0,1157 \pm 0,05$ & $0,1486 \pm 0,65$ & $0,314^{1}$ \\
Indeks Kelelahan Otot akhir & $0,1229 \pm 0,04$ & $0,1371 \pm 0,03$ & $0,532^{1}$ \\
\hline Independent $t$-test & \multicolumn{3}{|}{}
\end{tabular}

Berdasarkan hasil uji Independent t-test menunjukkan bahwa tidak ada perbedaan yang signifikan dengan nilai $(p>0,05)$ pada pengukuran indeks kelelahan otot sebelum dan sesudah penlitian pada kelompok perlakuan maupun kelompok kontrol.

Studi Brian Cunniffe (2016) menunjukkan bahwa suplementasi $12 \mathrm{~g}$ sitrulin dalam $400 \mathrm{ml}$ atau lemon cordial tidak memberikan manfaat ergogenic pada atlet. ${ }^{13} \mathrm{Hal}$ ini sejalan dengan penelitian Cutrufello yang menyatakan bahwa pemberian jus semangka dengan kandungan sitrulin $1 \mathrm{gr}$ dan $6 \mathrm{gr}$ tidak menunjukkan perubahan dalam kinerja aerobik dan fisiologis. Respon sitrulin dalam latihan anaerobik diketahui tetapi mekanisme sitrulin dalam latihan aerobik tidak jelas. ${ }^{6}$

4. Indeks Kelelahan Otot Menurut Kategori Pada Subjek Penelitian Sebelum dan Sesudah Penelitian antara Kelompok Perlakuan dan Kelompok Kontrol

Perbedaan indeks kelelahan otot pada kelompok perlakuan dan kelompok kontrol menururt kategori setelah satu minggu intervensi dengan pengukuran indeks kelelahan otot sebelum penelitian dan sesudah penelitian, yang diukur pada hari ke-1 dan ke-7 penelitian. Kategori indeks kelelahan otot dalam metode RAST yaitu; Sangat Baik apabila indeks kelelahan otot $(<0,21)$, baik apabila indeks kelelahan otot $(0,21-3,31)$, cukup apabila indeks kelelahan otot $(3,31-6,41)$, kurang apabila indeks kelelahan otot $(6,41-9.41)$, sangat kurang apabila indeks kelelahan otot $\geq 9,41$. Hasil analisis dapat dilihat pada tabel 4 .

Tabel 4 .

Indeks Kelelahan Otot Menurut Kategori Pada Subjek Penelitan Sebelum dan Sesudah Penelitian

\begin{tabular}{|c|c|c|c|c|}
\hline \multirow[t]{2}{*}{ Variabel } & \multicolumn{4}{|c|}{ Kelompok } \\
\hline & \multicolumn{2}{|c|}{ Perlakuan (n=7) } & \multicolumn{2}{|c|}{ Kontrol $(\mathbf{n}=7)$} \\
\hline Sebelum Penelitian & & & & \\
\hline Sangat Baik $(<0,21)$ & 6 & $85,7 \%$ & 5 & $71,4 \%$ \\
\hline Baik $(0,21-3,31)$ & 1 & $14,3 \%$ & 2 & $28,6 \%$ \\
\hline Total & 7 & $100 \%$ & 7 & $100 \%$ \\
\hline \multicolumn{5}{|l|}{ Selama Penelitian } \\
\hline Sangat Baik $(<0,21)$ & 7 & $100 \%$ & 7 & $100 \%$ \\
\hline Total & 7 & $100 \%$ & 7 & $100 \%$ \\
\hline
\end{tabular}

Berdasarkan tabel 4 kategori indeks kelelahan otot sebelum dan setelah penelitian apabila di lihat secara kategori mengalami kenaikan kategori, pada awal sebelum 
intervensi subjek penelitian termasuk dalam dua kategori indeks kelelahan otot yaitu ; sangat baik dengan nilai indeks kelelahan <0,21 dan baik dengan rentang indeks kelelahan 0,213,31 . Intervensi jus semangka kuning selama satu minggu mampu meningkatkan kategori indeks kelelahan otot pada kelompok perlakuan dan kelompok kontrol menjadi satu kategori yaitu; sangat baik dengan nilai indeks kelelahan $<0,21$.

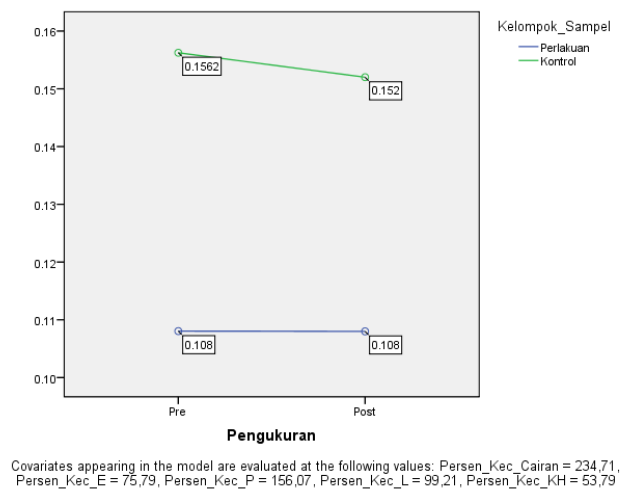

Gambar 1. Perbandingan indeks kelelahan otot yang diukur dengan menggunakan metode RAST sebelum dan sesudah penelitian pada kelompok perlakuan dan kontrol

Pada grafik Gambar 1 terlihat bahwa terdapat angka indeks kelelahan otot yang berbeda sebesar 0,0042 pada kelompok kontrol, dengan rerata skor pre-test sebelum 0,1562 wattss $/ \mathrm{sec}$ menjadi 0,152 wattss/sec pada skor post-test, angka tersebut tidak signifikan apabila dikatakan terjadi penurunan indeks kelelahan otot. Pada kelompok perlakuan tidak terlihat perubahan nilai indeks kelelahan otot pada pre-test dan post-test setelah diberikan treatment selama satu minggu yaitu dengan nilai indeks kelelahan otot 0,108 wattss/sec, dengan pemberian sitrulin yang terkandung dalam jus semangka kuning (citrullus lanatus) mampu membuat stabil sehingga kategori indeks kelelahan otot meningkat yang awalnya ada pada kategori baik $(0,21-3,31)$ menjadi sangat baik $(<0,21)$, meskipun secara uji statistik tidak secara signifikan mampu mengurangi kelelahan otot.

Penelitian lain yang dilakukan oleh Tsung-Han Liu dkk juga menyatakan bahwa tidak ada penurunan indeks kelelahan otot kelelahan selama latihan intensitas berat setelah 16 hari treatment pemberian jus semangka dengan kandungan sitrulin 3,4 gr/hari. ${ }^{14}$ Hasil penelitian Tsung-HanLiu et al (2008) menunjukkan bahwa suplementasi arginine jangka pendek tidak berpengaruh pada produksi oksida nitrat, metabolisme laktat dan amonia dan kinerja dalam latihan anaerobik intermiten pada atlet pria terlatih. ${ }^{15}$

Penurunan indeks kelelahan otot yang tidak signifikan antara kelompok perlakuan dan kelompok kontrol disebabkan karena adanya kemungkinan faktor lain yaitu kurangnya dosis sitrulin yang diberikan pada atlet, intervensi sitrulin pada jus semangka kurang lama, asupan zat gizi dan lamanya waktu latihan sebelum pengukuran indeks kelelahan ototyang dapat mempengaruhi kelelahan pada kedua kelompok.

\section{KESIMPULAN}

Pemberian jus semangka kuning (citrullus lanatus) dapat meningkatkan Indeks kelelahan otot dari kategori baik menjadi sangat baik meskipun secara statistik tidak signifikan ( $p>0.05$ ).

\section{SARAN}

Perlu diteliti selanjutnya dengan penambahan dosis sitrulin dan waktu intervensi serta kadar asam laktat pada atletik.

\section{DAFTAR PUSTAKA}

1. Irawan MA. Nutrisi, Energi, \& Performa Olahraga. Polt Sport Sci Perform Lab. 2007;1:1-13.

2. Kementrian Kesehatan RI. Pedoman Gizi Olahrga Prestasi. 2014. 11 P.

3. Mahan LK, Raymon JL. Krause's Food \& The Nutrition Care Process-Saunders. 14th Ed. 2016. 21-25 P.

4. Naz A, Butt MS, Sultan MT, Muhammad M, Qayyum N, Niaz RS. Review Article: Watermelon Lycopene And Allied Health Claims. Excli J [Internet]. 2014;13:650-66. Available From: Https://Www-Ncbi-Nlm-NihGov.Ezproxy.Baylor.Edu/Pmc/Articles/PMC44 64475/Pdf/EXCLI-13-650.Pdf

5. Tarazona-D MP, Alacid F, Mart I, Aguayo E. Watermelon Juice : Potential Functional Drink For Sore Muscle Relief In Athletes. J Agric Food Chem. 2013;61:522-7528.

6. Cutrufello PT, Gadomski SJ, Zavorsky GS. The Effect Of L-Citrulline And Watermelon Juice Supplementation On Anaerobic And Aerobic Exercise Performance. J Sports Sci. 2014;

7. Article O. Citrulline/Malate Promotes Aerobic Energy Production In Human Exercising Muscle. 2002;1:282-9.

8. I Made Yoga Parwata. Kelelahan Dan Recovery Dalam Olahraga. 2015;1:2-13. 
9. Ilyas E. Nutrisi Pada Atlet. Maj Gizi Med Indones. 2004;3:4-8.

10. Weatherwax D. Komposisi Tubuh Dan Efeknya Pada Spektrum Performa Olahraga. NSCA Sport Nutr. 2008;7:6-7.

11. Prista A, Maia JAR, Damasceno A, Beunen G. Anthropometric Indicators Of Nutritional Status: Implications For Fitness, Activity, And Health In School-Age Children And Adolescents From Maputo, Mozambique. Am J Clin Nutr [Internet]. 2003;77(4):952-9. Available

From: Https://Academic.Oup.Com/Ajcn/Article/77/ 4/952/4689772

12. Ui FKM. Sports And Recreational Activities,. 2009;

13. Cunniffe B, Papageorgiou M, O’Brien B, Davies
NA, Grimble GK, Cardinale M. Acute CitrullineMalate Supplementation And High-Intensity Cycling Performance. J Strength Cond Res. 2016;30(9):2638-47.

14. SJ B, JR B, E W, Al E. Two Weeks Of Watermelon Juice Supplementation Improves Nitric Oxide Bioavailability But Not Endurance Exercise Performance In Humans. Nitric Oxide. Appl Physiol Nutr Metab. 2016;59:10-20.

15. Tsung-Hanliu, Ching-Linwu, Chi-Weichiang, Yu-Weilod, Hung-Futseng, Chen-Kangchang. No Effect Of Short-Term Arginine Supplementation On Nitric Oxide Production, Metabolism And Performance In Intermittent Exercise In Athletes. J Nutr Biochem. 2009;20(6):462-8. 